\title{
Biomass Gasification Behavior in an Entrained Flow Reactor: Gas Product Distribution and Soot Formation
}

Qin, Ke; Jensen, Peter Arendt; Lin, Weigang; Jensen, Anker Degn

Published in:

Energy \& Fuels

Link to article, DOI:

10.1021/ef300960x

Publication date:

2012

Document Version

Publisher's PDF, also known as Version of record

Link back to DTU Orbit

Citation (APA):

Qin, K., Jensen, P. A., Lin, W., \& Jensen, A. D. (2012). Biomass Gasification Behavior in an Entrained Flow Reactor: Gas Product Distribution and Soot Formation. Energy \& Fuels, 26(9), 5992-6002.

https://doi.org/10.1021/ef300960x

\section{General rights}

Copyright and moral rights for the publications made accessible in the public portal are retained by the authors and/or other copyright owners and it is a condition of accessing publications that users recognise and abide by the legal requirements associated with these rights.

- Users may download and print one copy of any publication from the public portal for the purpose of private study or research.

- You may not further distribute the material or use it for any profit-making activity or commercial gain

- You may freely distribute the URL identifying the publication in the public portal 


\title{
Biomass Gasification Behavior in an Entrained Flow Reactor: Gas Product Distribution and Soot Formation
}

\author{
Ke Qin, Peter Arendt Jensen, Weigang Lin, and Anker Degn Jensen* \\ Department of Chemical and Biochemical Engineering, Technical University of Denmark, DK-2800 Kongens Lyngby, Denmark
}

Supporting Information

ABSTRACT: Biomass gasification and pyrolysis were studied in a laboratory-scale atmospheric pressure entrained flow reactor. Effects of operating parameters and biomass types on the syngas composition were investigated. In general, the carbon conversion during biomass gasification was higher than $90 \%$ at the optimal conditions of $1400{ }^{\circ} \mathrm{C}$ with steam addition. The biomass carbon that was not converted to gas in the gasification process only appeared as soot particles in the syngas in all of the experiments, except for the two experiments performed at $1000{ }^{\circ} \mathrm{C}$, where a very small amount of char was also left. In comparison to pyrolysis, lower yields of soot, $\mathrm{H}_{2}$, and $\mathrm{CO}$ were produced during gasification. The yield of soot could be reduced by a longer residence time, larger feeder air flow, lower oxygen concentration, higher excess air ratio, higher steam/carbon ratio, and higher reactor temperature. Changes in residence time, feeder air flow, and oxygen concentration did not show a noticeable influence on $\mathrm{H}_{2}$ and $\mathrm{CO}$ yields. Increasing the excess air ratio decreased both the $\mathrm{H}_{2}$ and $\mathrm{CO}$ yields; increasing the steam/carbon ratio increased the $\mathrm{H}_{2}$ yield but decreased the $\mathrm{CO}$ yield; and increasing the reactor temperature increased both the $\mathrm{H}_{2}$ and $\mathrm{CO}$ yields. Wood, straw, and dried lignin had similar gasification behavior, except with regard to soot formation. The soot yield was lowest during straw gasification possibly because of its high potassium content.

\section{INTRODUCTION}

Worldwide, biomass is the fourth largest energy resource after oil, coal, and gas. ${ }^{1,2}$ It is estimated that by 2050 biomass could supply $10-20 \%$ of the global primary energy requirements. ${ }^{1-3}$ Biomass is $\mathrm{CO}_{2}$-neutral and can thereby reduce the global greenhouse gas emissions. Three thermochemical conversion processes are available for biomass use: combustion, pyrolysis, and gasification. ${ }^{4}$ Gasification using pressurized fluidized bed or entrained flow gasifiers provides a syngas that can be used to synthesize liquid fuels and chemicals or produce heat and power by efficient combined-cycle power plants. ${ }^{5-7}$

Currently, coal gasification is the most commercially available technology in large scale. Biomass is an important alternative to coal but differs from coal in many important aspects, including lower carbon content, higher oxygen content, higher volatile content, lower heating value, and lower bulk density. ${ }^{8-10}$ Therefore, knowledge on biomass gasification is needed to support the development of commercial entrained flow biomass gasifiers. Entrained flow gasification operates at high temperatures $\left(>1200{ }^{\circ} \mathrm{C}\right)$ with rather small particles to achieve a high carbon conversion within a few seconds and may provide a highquality syngas, especially without tar. However, only a few experimental investigations ${ }^{11-15}$ are published on entrained flow gasification of biomass. These studies were mainly performed at relatively low temperatures $\left(<1200{ }^{\circ} \mathrm{C}\right)$ and investigated the effects of the reaction temperature, excess air ratio, residence time, particle size, and biomass type on gas composition. Steam addition and oxygen concentration, which might give a large influence on gasification behavior, ${ }^{16}$ were not studied in these references. Additionally, when biomass is pyrolyzed at high temperatures, secondary reactions occur in the gas phase, which converts tar compounds into light hydrocarbons, aromatics, oxygenate olefins, soot precursors, and soot. ${ }^{17-19}$ Unconverted soot in the syngas reduces the efficiency of the gasification process. In a previous experimental study, ${ }^{20}$ we investigated the influence of operating conditions on syngas composition during biomass gasification in an atmospheric pressure entrained flow reactor at high temperatures $\left(1000-1350{ }^{\circ} \mathrm{C}\right)$ with low oxygen concentrations $(5-10 \%)$. We found that a significant yield of soot was obtained at $1350{ }^{\circ} \mathrm{C}$, but there was nearly no yield of tar, probably because the heavy hydrocarbon chains were cracked and reacted with steam to form $\mathrm{H}_{2}, \mathrm{CO}$, and $\mathrm{CO}_{2}{ }^{21}$ A higher temperature was beneficial to lower the amount of tar, while the soot yield showed a peak at $1200^{\circ} \mathrm{C}$, which may result from soot formation by tar and hydrocarbon polymerization competing with soot gasification by $\mathrm{CO}_{2}$ and $\mathrm{H}_{2} \mathrm{O}$ at high temperatures. Thus, high temperature and steam addition are helpful to provide a syngas product rich in $\mathrm{H}_{2}$ and $\mathrm{CO}$ with a low soot content.

As a continuation of the previous study, the main objective of the present work is to comprehensively investigate the effects of operating parameters and biomass types on gas product distribution and soot formation in air/steam entrained flow gasification and to determine favorable conditions for achieving complete biomass conversion. The investigated reactor temperature is up to $1400{ }^{\circ} \mathrm{C}$, and the inlet oxygen concentration is $21 \%$ in most of the experiments. Six gasification parameters (residence time, feeder air flow, oxygen concentration, excess air ratio, steam/ carbon ratio, and reactor temperature) and three biomasses (wood, straw, and lignin, a waste product from bioethanol production) are investigated in the present study. Besides a systematic study on

Received: June 4, 2012

Revised: August 2, 2012 
biomass gasification, biomass pyrolysis is also investigated to support a deeper understanding of the whole gasification process.

\section{EXPERIMENTAL SECTION}

Wood (beech sawdust) and straw (pulverized wheat straw pellet) were the main biomass fuels used in this study, while dried lignin gasification was tested in a single experiment for comparison. The lignin, which was obtained as a byproduct from a straw ethanol plant, had a high moisture content (69.2 wt \%, on an as-received basis). In the pretreatment process, most of the moisture was removed by suction filtration and the solid residues were dried at $105{ }^{\circ} \mathrm{C}$ for $24 \mathrm{~h}$. In order to attain a stable feeding, the dried lignin was sieved to the desired particle size $(<1 \mathrm{~mm})$. The properties of wood, straw, and dried lignin are listed in Table 1.

\section{Table 1. Properties of Fuels}

\begin{tabular}{|c|c|c|c|}
\hline properties & $\begin{array}{l}\text { wood (on an as- } \\
\text { received basis) }\end{array}$ & $\begin{array}{l}\text { straw (on an as- } \\
\text { received basis) }\end{array}$ & $\begin{array}{l}\text { dried lignin (on } \\
\text { a dry basis) }\end{array}$ \\
\hline moisture (wt \%) & 9.04 & 5.40 & 0.00 \\
\hline ash (wt \%) & 0.61 & 4.54 & 11.10 \\
\hline volatile (wt \%) & 76.70 & 72.27 & 63.10 \\
\hline $\begin{array}{l}\text { fixed carbon (wt \%) } \\
\text { (by difference) }\end{array}$ & 13.65 & 17.79 & 25.80 \\
\hline $\begin{array}{l}\text { lower heating value } \\
(\mathrm{MJ} / \mathrm{kg})\end{array}$ & 16.44 & 16.35 & 21.42 \\
\hline C (wt \%) & 45.05 & 43.42 & 53.80 \\
\hline $\mathrm{H}($ wt \%) & 5.76 & 5.58 & 5.70 \\
\hline $\begin{array}{l}\mathrm{O} \text { (wt \%) } \\
\text { (by difference) }\end{array}$ & 39.41 & 40.60 & 28.10 \\
\hline $\mathrm{N}($ wt \%) & 0.13 & 0.37 & 1.18 \\
\hline S (wt \%) & 0.01 & 0.09 & 0.12 \\
\hline Si (wt \%) & & 1.23 & 4.18 \\
\hline $\mathrm{K}(\mathrm{wt} \%)$ & & 0.76 & 0.13 \\
\hline $\mathrm{Cl}$ (wt \%) & & 0.25 & 0.02 \\
\hline $\mathrm{Ca}($ wt \%) & & 0.23 & 0.43 \\
\hline $\operatorname{Mg}($ wt \%) & & 0.06 & 0.02 \\
\hline $\mathrm{P}(\mathrm{wt} \%)$ & & 0.03 & 0.06 \\
\hline $\mathrm{Na}($ wt \%) & & 0.01 & 0.28 \\
\hline $\mathrm{Al}($ wt \%) & & 0.01 & 0.07 \\
\hline $\mathrm{Fe}(\mathrm{wt} \%)$ & & 0.01 & 0.30 \\
\hline
\end{tabular}

It can be seen that the compositions of wood and straw are quite similar, except for the ash content. The potassium content in straw is high. In comparison to wood and straw, the dried lignin has a higher heating value and fixed carbon content, lower volatile content, and higher ash content, being rich in silica. The particle size distributions, shown in Figure 1, were

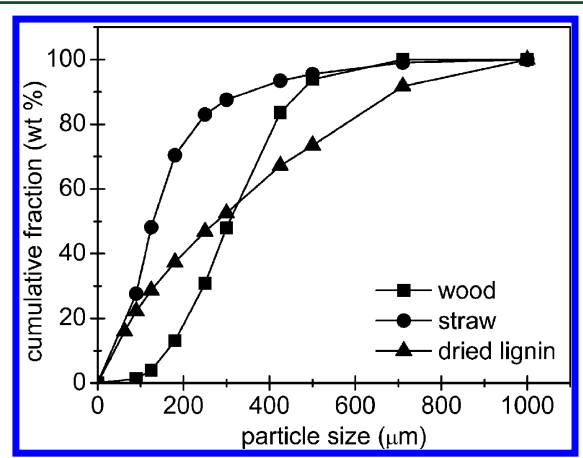

Figure 1. Particle size distributions of fuels.

determined by sieve classification. The median diameters $\left(d_{50}\right)$ of wood, straw, and dried lignin were 310,130 , and $280 \mu \mathrm{m}$, respectively.

All experiments, listed in Table 2, were carried out in an atmospheric pressure entrained flow reactor. The experimental setup is illustrated in Figure 2. It is comprised of a fuel feeding system, gas supply system, gas preheater, vertical reactor, bottom chamber, product sampling system, gas analysis system, and flue gas treatment system. The gas preheater is located on the top of the reactor and consists of two electrical heating elements. The $\mathrm{SiC}$ reaction tube inside the reactor has a length of $2 \mathrm{~m}$ with an inner diameter of $0.08 \mathrm{~m}$ and is externally heated by seven independent electrical heating elements to obtain a maximum temperature of $1500{ }^{\circ} \mathrm{C}$. A more detailed description of the setup can be found elsewhere. ${ }^{20}$

During the experiments, biomass particles $(6.4-15.9 \mathrm{~g} / \mathrm{min})$ were carried into the reactor by the cold feeder gas stream $(6-14 \mathrm{NL} / \mathrm{min}$ $\mathrm{N}_{2}$ or air). Preheated gas $\left(2.1-10.2 \mathrm{NL} / \mathrm{min} \mathrm{N}_{2}\right.$, air, or gas mixtures of $\mathrm{O}_{2}$ and $\left.\mathrm{N}_{2}\right)$ and steam $(0.0-517.9 \mathrm{~g} / \mathrm{min})$ entered the reactor through the main gas stream. A purge gas stream $\left(2.7 \mathrm{NL} / \mathrm{min} \mathrm{N}_{2}\right.$ and $0.3 \mathrm{NL} / \mathrm{min}$ air) was employed to protect the heating elements. The syngas products were sampled at the bottom outlet of the reactor. The gas samples were dried and then analyzed by a nondispersive infrared (NDIR) gas analyzer and a micro gas chromatograph (Agilent 3000). The analytical error from these two equipments is less than $5 \%$. The gas measurement involved the concentration of $\mathrm{H}_{2}, \mathrm{CO}$, $\mathrm{CO}_{2}$, and $\mathrm{C}_{x} \mathrm{H}_{y}$ (total amount of light hydrocarbons, including $\mathrm{CH}_{4}$, $\mathrm{C}_{2} \mathrm{H}_{4}$, and $\mathrm{C}_{2} \mathrm{H}_{2}$ ). Samples of solid products, char and soot, were collected by a cyclone and a metal filter, which were heated to $400{ }^{\circ} \mathrm{C}$ to avoid tar condensation. After the heated metal filter, a Petersen column, ${ }^{22}$ which was filled with acetone as the solvent and cooled to $0{ }^{\circ} \mathrm{C}$, was employed to capture tar samples when the experiments were conducted at $1000{ }^{\circ} \mathrm{C}$. Each experiment lasted approximately $60 \mathrm{~min}$. A more detailed description of the experimental procedures is available elsewhere. $^{23}$

To determine the soot content, the solid samples from the metal filter were analyzed by a thermogravimetric apparatus (Netzsch STA-449C). In these experiments, $5 \mathrm{mg}$ samples were loaded in a platinum crucible and heated at $10{ }^{\circ} \mathrm{C} / \mathrm{min}$ to the final setting temperature. The temperature program and applied gas environment for the simultaneous thermal analysis (STA) is shown in Figure 3. In the analysis, different phases of the sample, such as moisture, volatiles, fixed carbon, volatilizable inorganic compounds, and residual ash, can be successfully separated and detected. The amount of soot was defined as the total weight of volatiles and fixed carbon. To determine the tar content in the solvent (acetone), the solvent of the liquid sample was evaporated by two different ways, at $60{ }^{\circ} \mathrm{C}$ for $1.5 \mathrm{~h}$ and at room temperature for $5.5 \mathrm{~h}$, respectively, and then the residues were considered as the tar compounds.

\section{RESULTS AND DISCUSSION}

3.1. Mass Balance. In all conducted experiments, listed in Table 2, soot was always observed but no unreacted char was collected, except in two experiments conducted at $1000{ }^{\circ} \mathrm{C}$. Hardly any amount of ash was found in the cyclone, but small amounts of ash were collected with the soot captured by the metal filter. The small amount of ash collected is probably because, at high temperatures, most ash melted and deposited on the reactor walls and that cannot be collected by the solid sampling system. After both of the two ways of evaporating the solvent, no tar was found in the liquid sample collected at $1000{ }^{\circ} \mathrm{C}$, maybe partly because some light compounds in the tar were not captured during the liquid sampling process and maybe partly because the light compounds escaped during the solvent evaporation process. The carbon mass balance is depicted in Figure 4 (the detailed data are listed in the Supporting Information). It was calculated on the basis of the fuel composition, fuel feeding rate, and yields of $\mathrm{CO}, \mathrm{CO}_{2}, \mathrm{C}_{x} \mathrm{H}_{y}$, and soot. At $1000{ }^{\circ} \mathrm{C}$, a very small amount of char was observed, and it could contribute $0.1-0.2 \%$ to the overall carbon mass balance; thus, this insignificant contribution was not shown in Figure 4. In all conducted experiments, most fuel carbon was partitioned to $\mathrm{CO}$ and $\mathrm{CO}_{2}$. When the temperature was decreased, the contribution of $\mathrm{C}_{x} \mathrm{H}_{y}$ increased gradually. Soot also gave a significant contribution to the closure of the carbon 
Table 2. List of Conducted Experiments

\begin{tabular}{|c|c|c|c|c|c|c|c|c|c|}
\hline \multicolumn{10}{|c|}{ (a) Pyrolysis Experiments } \\
\hline parameter & number & fuel & fuel feeding rate $(\mathrm{g} / \mathrm{min})$ & $t(\mathrm{~s})$ & \multicolumn{3}{|c|}{ feeder $\mathrm{N}_{2}$ flow $(\mathrm{NL} / \mathrm{min})$} & $\mathrm{H}_{2} \mathrm{O} / \mathrm{C}(\mathrm{mol} / \mathrm{mol})$ & $T\left({ }^{\circ} \mathrm{C}\right)$ \\
\hline \multirow{3}{*}{ steam/carbon ratio $\left(\mathrm{H}_{2} \mathrm{O} / \mathrm{C}\right)$} & wP1 & wood & 12.8 & 2.8 & \multicolumn{3}{|c|}{10} & 1.0 & 1400 \\
\hline & wP2 & wood & 12.8 & 2.7 & \multicolumn{3}{|c|}{10} & 0.5 & 1400 \\
\hline & $\mathrm{wP}^{a}$ & wood & 12.8 & 2.6 & \multicolumn{3}{|c|}{10} & 0.0 & 1400 \\
\hline \multicolumn{10}{|c|}{ (b) Gasification Experiments } \\
\hline parameter & number & fuel & fuel feeding rate $(\mathrm{g} / \mathrm{min})$ & $t(\mathrm{~s})$ & $\mathrm{FAL}(\mathrm{NL} / \mathrm{min})$ & $\mathrm{O}_{2}(\%)$ & $\lambda$ & $\mathrm{H}_{2} \mathrm{O} / \mathrm{C}(\mathrm{mol} / \mathrm{mol})$ & $T\left({ }^{\circ} \mathrm{C}\right)$ \\
\hline \multirow{6}{*}{ residence time $(t)$} & wR1 & wood & 10.7 & 3.7 & 10 & 21 & 0.30 & 0.5 & 1400 \\
\hline & $\mathrm{wR} 2^{a}$ & wood & 12.8 & 3.1 & 10 & 21 & 0.30 & 0.5 & 1400 \\
\hline & wR3 & wood & 15.9 & 2.5 & 10 & 21 & 0.30 & 0.5 & 1400 \\
\hline & wR4 & wood & 6.4 & 5.9 & 6 & 21 & 0.30 & 0.5 & 1400 \\
\hline & wR5 & wood & 12.8 & 3.1 & 6 & 21 & 0.30 & 0.5 & 1400 \\
\hline & $\mathrm{wF} 1$ & wood & 12.8 & 3.1 & 14 & 21 & 0.30 & 0.5 & 1400 \\
\hline \multirow{4}{*}{ feeder air flow (FAL) } & $\mathrm{wF} 2^{a}$ & wood & 12.8 & 3.1 & 10 & 21 & 0.30 & 0.5 & 1400 \\
\hline & wF3 & wood & 12.8 & 3.1 & 6 & 21 & 0.30 & 0.5 & 1400 \\
\hline & $\mathrm{wF} 4$ & wood & 15.9 & 2.5 & 18 & 21 & 0.30 & 0.5 & 1400 \\
\hline & $\mathrm{wF5}$ & wood & 15.9 & 2.5 & 10 & 21 & 0.30 & 0.5 & 1400 \\
\hline \multirow{8}{*}{ oxygen concentration $\left(\mathrm{O}_{2}\right)$} & wO1 & wood & 15.8 & 2.8 & 10 & 26 & 0.30 & 0.5 & 1400 \\
\hline & $\mathrm{wO} 2^{a}$ & wood & 12.8 & 3.1 & 10 & 21 & 0.30 & 0.5 & 1400 \\
\hline & wO3 & wood & 9.7 & 3.4 & 10 & 16 & 0.30 & 0.5 & 1400 \\
\hline & wO4 & wood & 12.8 & 3.1 & 6 & 21 & 0.30 & 0.5 & 1400 \\
\hline & wO5 & wood & 6.7 & 3.7 & 6 & 11 & 0.30 & 0.5 & 1400 \\
\hline & sO1 & straw & 15.9 & 2.8 & 10 & 26 & 0.30 & 0.5 & 1400 \\
\hline & $\mathrm{sO} 2$ & straw & 12.8 & 3.1 & 10 & 21 & 0.30 & 0.5 & 1400 \\
\hline & sO3 & straw & 9.8 & 3.4 & 10 & 16 & 0.30 & 0.5 & 1400 \\
\hline \multirow{6}{*}{ excess air ratio $(\lambda)$} & wL1 & wood & 10.9 & 3.4 & 10 & 21 & 0.35 & 0.5 & 1400 \\
\hline & $\mathrm{wL} 2^{a}$ & wood & 12.8 & 3.1 & 10 & 21 & 0.30 & 0.5 & 1400 \\
\hline & wL3 & wood & 15.3 & 2.8 & 10 & 21 & 0.25 & 0.5 & 1400 \\
\hline & sL1 & straw & 11.0 & 3.4 & 10 & 21 & 0.35 & 0.5 & 1400 \\
\hline & sL2 & straw & 12.8 & 3.1 & 10 & 21 & 0.30 & 0.5 & 1400 \\
\hline & sL3 & straw & 15.4 & 2.8 & 10 & 21 & 0.25 & 0.5 & 1400 \\
\hline \multirow{6}{*}{ steam/carbon ratio $\left(\mathrm{H}_{2} \mathrm{O} / \mathrm{C}\right)$} & wH1 & wood & 12.8 & 3.0 & 10 & 21 & 0.30 & 1.0 & 1400 \\
\hline & $\mathrm{wH} 2^{a}$ & wood & 12.8 & 3.1 & 10 & 21 & 0.30 & 0.5 & 1400 \\
\hline & wH3 & wood & 12.8 & 3.2 & 10 & 21 & 0.30 & 0.0 & 1400 \\
\hline & sH1 & straw & 12.8 & 3.0 & 10 & 21 & 0.30 & 1.0 & 1400 \\
\hline & $\mathrm{sH} 2$ & straw & 12.8 & 3.1 & 10 & 21 & 0.30 & 0.5 & 1400 \\
\hline & sH3 & straw & 12.8 & 3.2 & 10 & 21 & 0.30 & 0.0 & 1400 \\
\hline \multirow{11}{*}{ reactor temperature $(T)$} & $\mathrm{wT} 1^{a}$ & wood & 12.8 & 3.1 & 10 & 21 & 0.30 & 0.5 & 1400 \\
\hline & wT2 & wood & 12.8 & 3.4 & 10 & 21 & 0.30 & 0.5 & 1300 \\
\hline & wT3 & wood & 12.8 & 3.8 & 10 & 21 & 0.30 & 0.5 & 1200 \\
\hline & wT4 & wood & 12.8 & 4.2 & 10 & 21 & 0.30 & 0.5 & 1100 \\
\hline & wT5 & wood & 12.8 & 4.7 & 10 & 21 & 0.30 & 0.5 & 1000 \\
\hline & sT1 & straw & 12.8 & 3.1 & 10 & 21 & 0.30 & 0.5 & 1400 \\
\hline & $\mathrm{sT} 2$ & straw & 12.8 & 3.4 & 10 & 21 & 0.30 & 0.5 & 1300 \\
\hline & sT3 & straw & 12.8 & 3.8 & 10 & 21 & 0.30 & 0.5 & 1200 \\
\hline & sT4 & straw & 12.8 & 4.4 & 10 & 21 & 0.30 & 0.5 & 1100 \\
\hline & sT5 & straw & 12.8 & 5.0 & 10 & 21 & 0.30 & 0.5 & 1000 \\
\hline & $\mathrm{dl}$ & dried lignin & 9.8 & 3.1 & 10 & 21 & 0.30 & 0.5 & 1400 \\
\hline
\end{tabular}

mass balance in the pyrolysis experiments. The carbon mass balance closure was reasonable and, in most cases, higher than 95\%, except for a few experiments conducted at 1000 and $1100{ }^{\circ} \mathrm{C}(13-21 \%$ gap). The most likely reason is that, at lower temperatures, some carbonaceous products, for instance unreacted char, soot, and tar, were deposited on the reactor walls and were not totally oxidized and gasified and, thereby, were not included in the carbon mass balance calculation. The water yields in the syngas were not determined, and therefore, the hydrogen and oxygen mass balance could not close and are not shown in the present paper. To compare the experimental results for dried lignin, wood, and straw gasification with equilibrium conditions, equilibrium calculations were conducted using the FactSage program for experiments wT1, sT1, and dl, listed in Table 2. There was no carbon left in the equilibrium calculation; therefore, the equilibrium syngas consisted of $\mathrm{CO}, \mathrm{CO}_{2}, \mathrm{H}_{2}$, and $\mathrm{H}_{2} \mathrm{O}$. The product distributions of experiments and equilibrium calculations are compared in Figure 5. The majority of the undetermined product is water in these experiments (highest temperature with steam addition). Generally, the experimental results were reasonably similar to the equilibrium calculation results. 


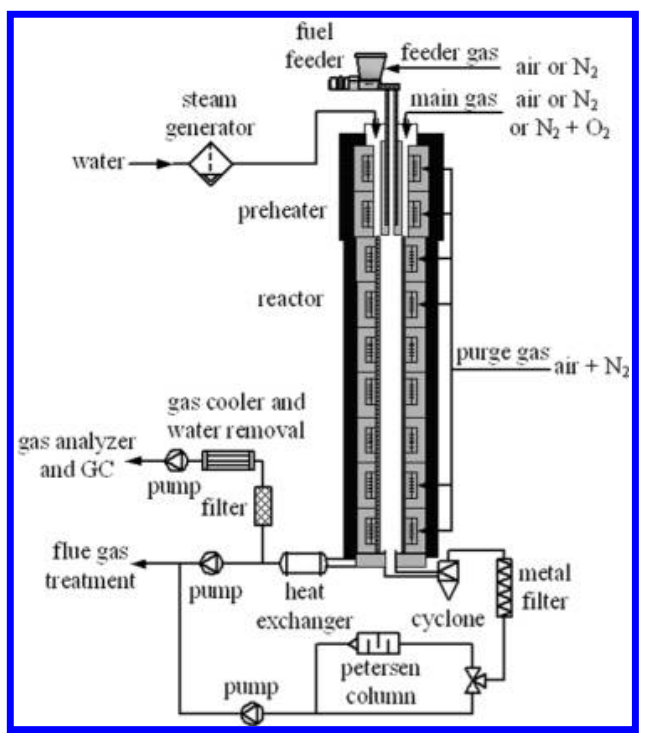

Figure 2. Sketch of the experimental setup.

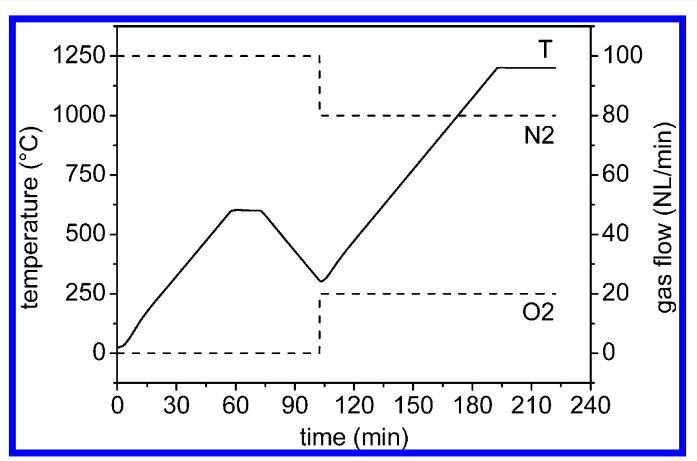

Figure 3. Temperature program with a gas environment for STA.

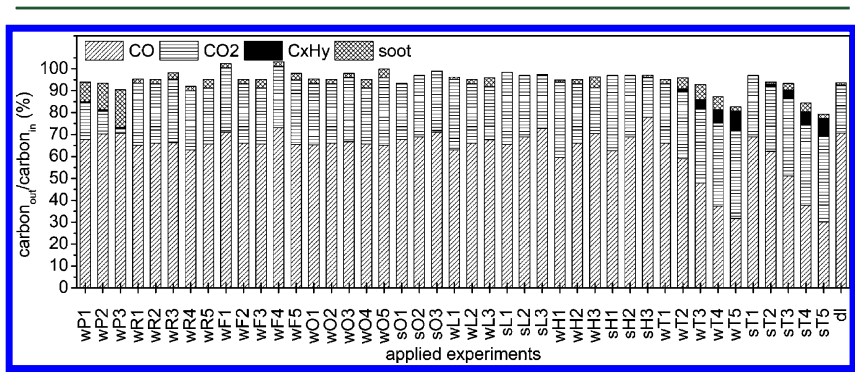

Figure 4. Carbon balances for all conducted experiments listed in Table 2.

3.2. Comparison between Pyrolysis and Gasification.

Figure 6 shows the soot and gas yields during wood pyrolysis and gasification at $1400{ }^{\circ} \mathrm{C}$ with different steam addition levels. $10 \mathrm{NL} / \mathrm{min} \mathrm{N}_{2}$ and air were employed as feeder gas in the pyrolysis and gasification experiments, respectively. During gasification, the applied oxygen concentration was $21 \%$ and the excess air ratio was 0.3. Without steam addition, the soot yield was $85.5 \mathrm{~g} / \mathrm{kg}$ fuel (dry and ash-free basis, daf) during pyrolysis and $23.6 \mathrm{~g} / \mathrm{kg}$ fuel (daf basis) during gasification. The lower soot yield during gasification is most likely both because of more oxidizing conditions at the top of the reactor, leading to oxidation of the tar to lighter molecules, and because more soot was oxidized and gasified. The relative importance of these two contributions however could not be determined by these experiments. With steam addition, the same tendency of the

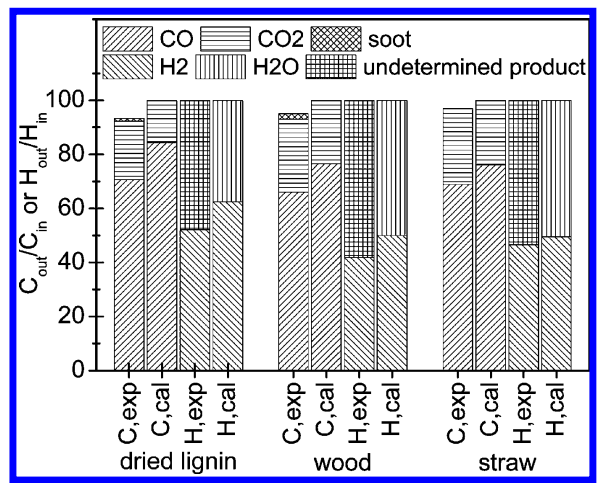

Figure 5. Comparison between the results of the experiment and equilibrium calculation. The selected experiments are wT1, sT1, and dl, listed in Table 2, with fixed operating parameters (feeder air flow $=10$ $\mathrm{NL} / \mathrm{min}$; oxygen concentration $=21 \%$; excess air ratio $=0.3$; steam $/$ carbon ratio $=0.5$; and reactor temperature $=1400^{\circ} \mathrm{C}$ ). C, $\exp$ and $\mathrm{H}, \exp$ are the carbon and hydrogen balance in the experiment. C,cal and $\mathrm{H}$,cal are the carbon and hydrogen balance in the equilibrium calculation.

soot yield was observed in Figure 6. As a result, the soot yield was approximately $70-90 \%$ lower in the gasification experiments than in the pyrolysis experiments. During gasification, the $\mathrm{H}_{2}$ and $\mathrm{CO}$ yields were lower and no $\mathrm{C}_{x} \mathrm{H}_{y}$ was produced, while the $\mathrm{CO}_{2}$ yield was higher because of more oxidizing conditions. It should be noted that during pyrolysis without steam addition the $\mathrm{CO}_{2}$ yield $\left(0.02 \mathrm{Nm}^{3} / \mathrm{kg}\right.$ fuel (daf basis)) was very low, probably because $\mathrm{CO}_{2}$ was consumed by char and soot gasification reactions.

3.3. Effects of Gasification Parameters. 3.3.1. Residence Time. Figure 7 shows the effect of the residence time on the product yield during wood gasification. The two studied ranges of residence time are $2.5-3.7 \mathrm{~s}$ with a feeder air flow of $10 \mathrm{NL} /$ min and 3.1-5.9 s with a feeder air flow of $6 \mathrm{NL} / \mathrm{min}$ with otherwise fixed operating parameters (oxygen concentration $=$ $21 \%$; excess air ratio $=0.3$; steam $/$ carbon ratio $=0.5$; and reactor temperature $=1400^{\circ} \mathrm{C}$ ). The longer residence time was achieved by decreasing the fuel feeding rate and the total inlet gas flow. The estimated residence time was calculated on the basis of the reactor size and the total flow of the syngas. In Figure 7a, the soot yield decreased slightly from 15.5 to $9.8 \mathrm{~g} / \mathrm{kg}$ fuel (daf basis) as the residence time increased from 2.5 to $3.7 \mathrm{~s}$, because more soot was gasified at the longer residence time. However, the individual gas yields were almost kept constant, probably because the experimental conditions were close to the equilibrium conditions. ${ }^{11,12,20,24-26}$ In Figure 7b, similar trends of soot and gas product yields were obtained when the residence time was further increased from 3.1 to $5.9 \mathrm{~s}$ with a feeder air flow of $6 \mathrm{NL} / \mathrm{min}$.

3.3.2. Feeder Air Flow. The effect of the feeder air flow on the product yield during wood gasification is depicted in Figure 8 . The applied feeder air flow was increased from 6 to $14 \mathrm{NL} / \mathrm{min}$ at a residence time of $3.1 \mathrm{~s}$ and from 10 to $18 \mathrm{NL} / \mathrm{min}$ at a residence time of $2.5 \mathrm{~s}$, while all other operating parameters were fixed (oxygen concentration $=21 \%$; excess air ratio $=0.3$; steam $/$ carbon ratio $=0.5$; and reactor temperature $=1400^{\circ} \mathrm{C}$ ). Figure 8a shows that the soot yield decreased from 21.4 to $10.2 \mathrm{~g} / \mathrm{kg}$ fuel (daf basis) when the feeder air flow was increased from 6 to $14 \mathrm{NL} / \mathrm{min}$, while the yield of the individual gas species increased a little. It is probably because the increasing feeder air flow improved the mixing at the top of the reactor, which enhanced tar being converted to light gases instead of soot. The results show that mixing is very important for the formation of soot. Similar results in another range of applied feeder air flow from 10 to $18 \mathrm{NL} / \mathrm{min}$ is shown in Figure $8 \mathrm{~b}$. 


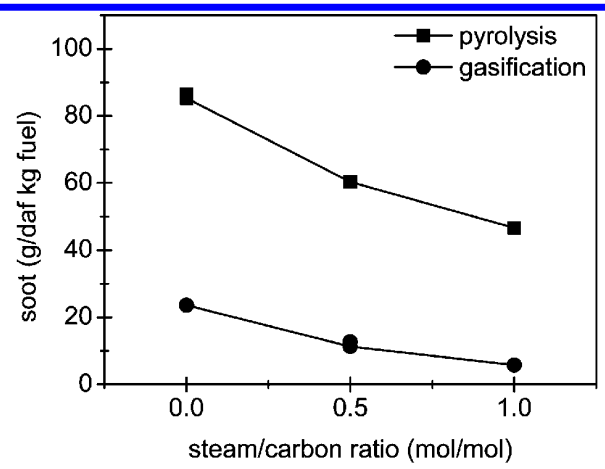

(a) soot

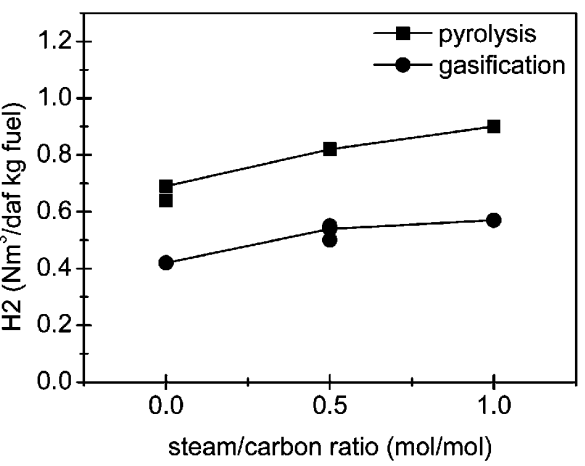

(b) $\mathrm{H}_{2}$

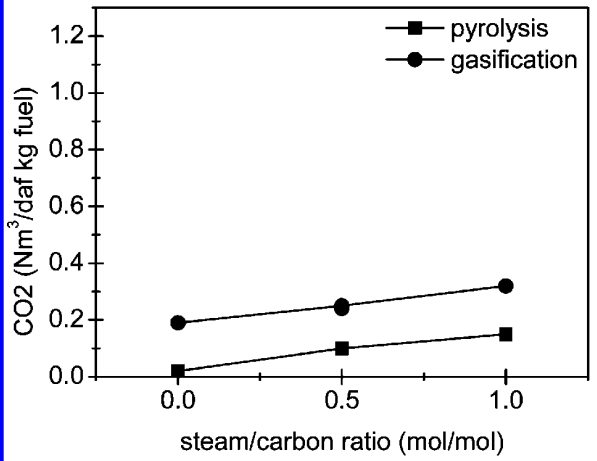

(d) $\mathrm{CO}_{2}$

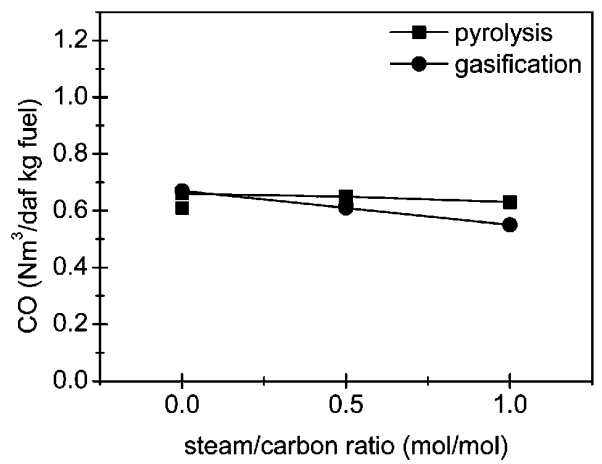

(c) $\mathrm{CO}$

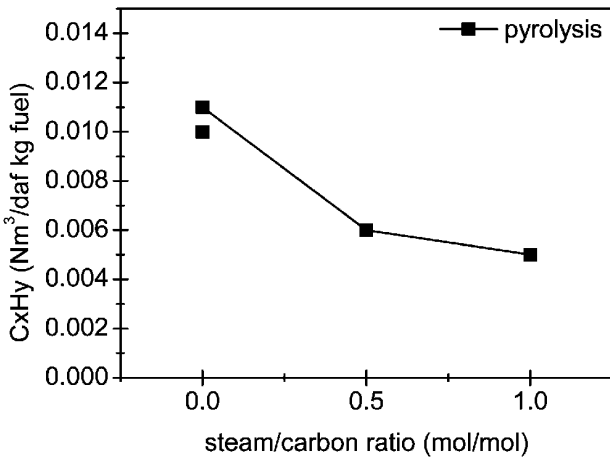

(e) $\mathrm{C}_{\mathrm{x}} \mathrm{H}_{\mathrm{y}}$

Figure 6. Comparison between wood pyrolysis and gasification at $1400^{\circ} \mathrm{C}$. During pyrolysis, $\mathrm{N}_{2}$ was employed as the inlet gas and $10 \mathrm{NL} / \mathrm{min} \mathrm{N}_{2}$ was used as the feeder gas. During gasification, air was employed as the inlet gas, $10 \mathrm{NL} / \mathrm{min}$ air was used as feeder gas, and the oxygen concentration and excess air ratio were $21 \%$ and 0.3 , respectively.

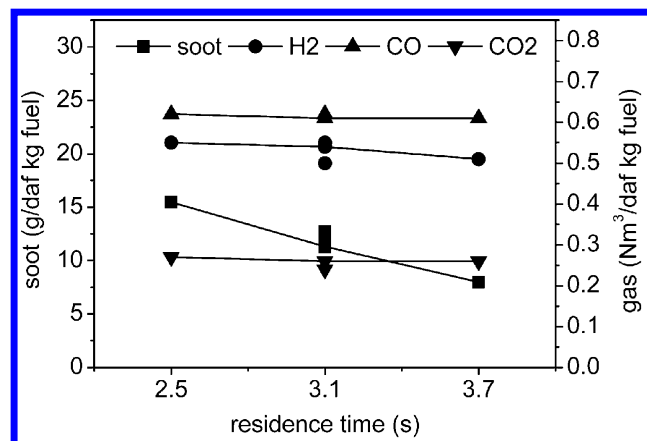

(a) feeder air flow $=10 \mathrm{NL} / \mathrm{min}$

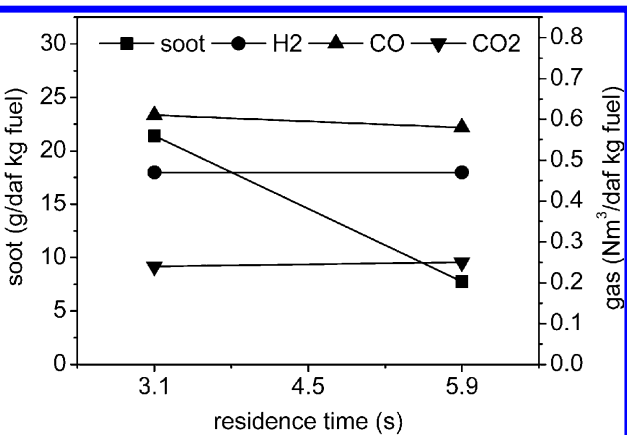

(b) feeder air flow $=6 \mathrm{NL} / \mathrm{min}$

Figure 7. Effect of the residence time on the product yield during wood gasification: oxygen concentration $=21 \%$; excess air ratio $=0.3$; steam $/$ carbon ratio $=0.5$; and reactor temperature $=1400^{\circ} \mathrm{C}$.

The obtained mixing condition during combustion and gasification can be revealed by flame observation. The condition at the top part of the reactor could be visually observed by removing the bottom probe. Figure 9 shows the flame structures of wood combustion (excess air ratio $=1.1$ ) at $1000{ }^{\circ} \mathrm{C}$ with different feeder air flows. A central flame can be observed clearly 


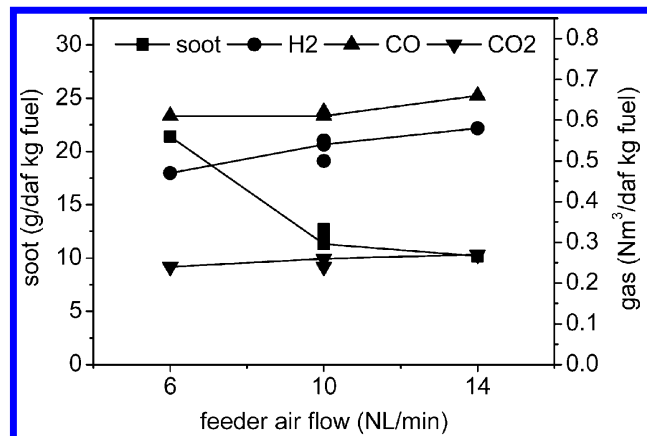

(a) fuel feeding rate $=12.8 \mathrm{~g} / \mathrm{min}$ (residence time $=3.1 \mathrm{~s}$ )

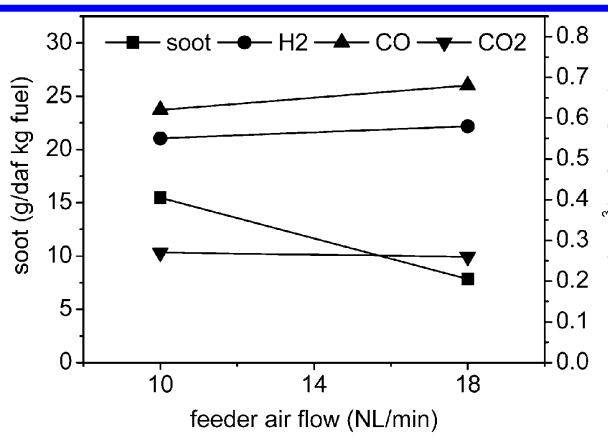

(b) fuel feeding rate $=15.9 \mathrm{~g} / \mathrm{min}$ (residence time $=2.5 \mathrm{~s}$ )

Figure 8. Effect of the feeder air flow on the product yield during wood gasification: oxygen concentration $=21 \%$; excess air ratio $=0.3$; steam $/$ carbon ratio $=0.5$; and reactor temperature $=1400{ }^{\circ} \mathrm{C}$.

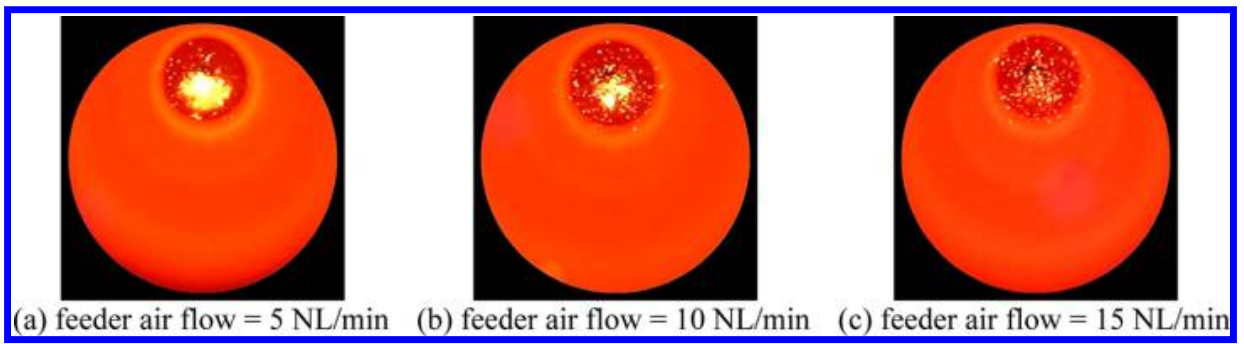

Figure 9. Flame structure at $1000{ }^{\circ} \mathrm{C}$ with an excess air ratio of 1.1 during wood combustion (fuel feeding rate $=3.3 \mathrm{~g} / \mathrm{min}$ ).

in Figure 9a with the feeder air flow of $5 \mathrm{NL} / \mathrm{min}$. This figure shows that the released volatiles from single fuel particles did not mix with oxygen instantly but accumulated together to form volatile clouds, which delayed the gas oxidation and formed a central flame. Figure $9 \mathrm{~b}$ shows that a smaller central flame surrounded by many single burning particles was obtained by increasing the feeder air flow to $10 \mathrm{NL} / \mathrm{min}$, which represented an improved mixing compared to Figure 9a. Many single particle flames, without an overall flame envelope, were observed with a feeder air flow of $15 \mathrm{NL} / \mathrm{min}$ in Figure 9c, meaning that the released volatile gases were immediately oxidized. Therefore, it can be concluded that faster mixing can be obtained by increasing the feeder air flow. Moreover, the flame behavior during wood gasification (excess air ratio $=0.7$ ) at $1000^{\circ} \mathrm{C}$ with different feeder air flows is exhibited in Figure 10. A comparison

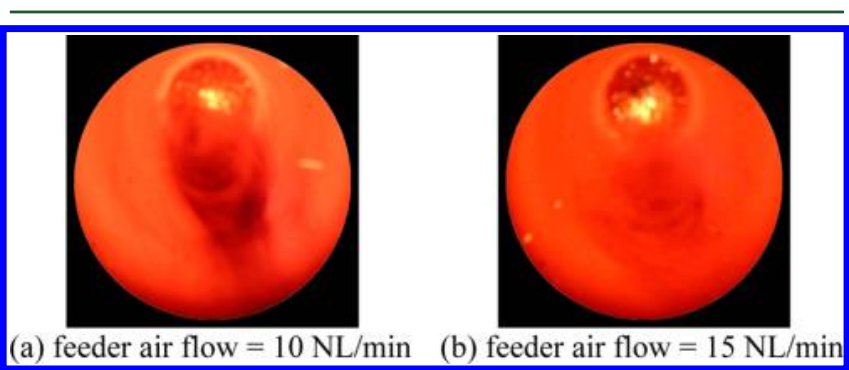

Figure 10. Flame structure at $1000{ }^{\circ} \mathrm{C}$ with an excess air ratio of 0.7 during wood gasification (fuel feeding rate $=5.0 \mathrm{~g} / \mathrm{min}$ ).

between Figure 10a and 10b shows that, with the lower feeder air flow, more soot was generated, which was consistent with the experimental results. As a result, these observations reinforce the conclusion that a larger feeder air flow could improve the mixing condition and thereby decrease the soot formation.
3.3.3. Oxygen Concentration and Excess Air Ratio. The combined effects of the oxygen concentration and excess air ratio on the product yield during wood gasification at $1350{ }^{\circ} \mathrm{C}$ with a steam/carbon ratio of 0.5 and a feeder air flow of $10 \mathrm{NL} / \mathrm{min}$ were investigated in our previous study, ${ }^{20}$ depicted in Figure 11.

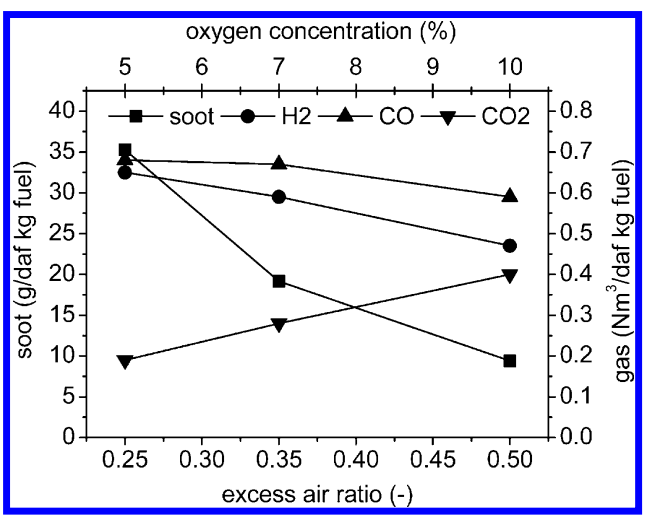

Figure 11. Combined effects of the oxygen concentration and excess air ratio on the product yield during wood gasification at $1350{ }^{\circ} \mathrm{C}$ with a steam/carbon ratio of 0.5 and a feeder air flow of $10 \mathrm{NL} / \mathrm{min}^{20}$

It was found that increasing the excess air ratio by increasing the oxygen concentration decreased the soot, $\mathrm{H}_{2}$, and $\mathrm{CO}$ yields but increased the $\mathrm{CO}_{2}$ yield. The effects of the oxygen concentration and excess air ratio on syngas product yields during wood and straw gasification were studied independently in the present study. The effect of the oxygen concentration on the product yield during wood and straw gasification is depicted in Figure 12. The studied ranges of the oxygen concentration were $16-26 \%$ with a feeder air flow of $10 \mathrm{NL} / \mathrm{min}$ and $11-21 \%$ with a feeder air flow of $6 \mathrm{NL} / \mathrm{min}$, while all other operating parameters were fixed (excess air ratio $=0.3$; steam $/$ carbon ratio $=0.5$; and 


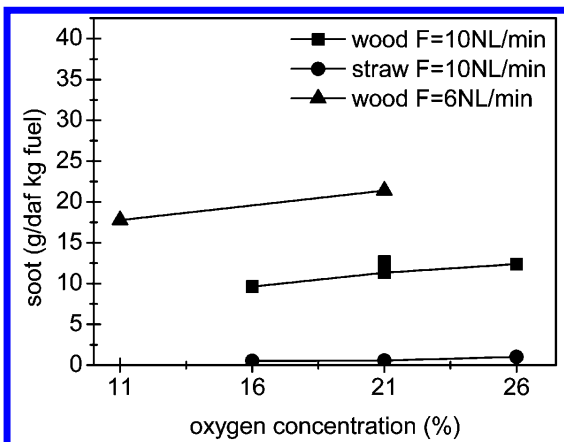

(a) soot

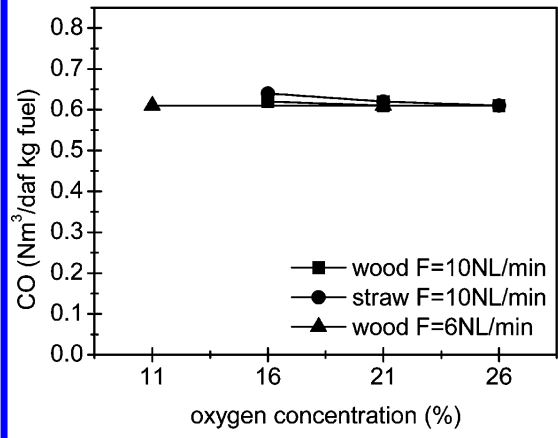

(c) $\mathrm{CO}$

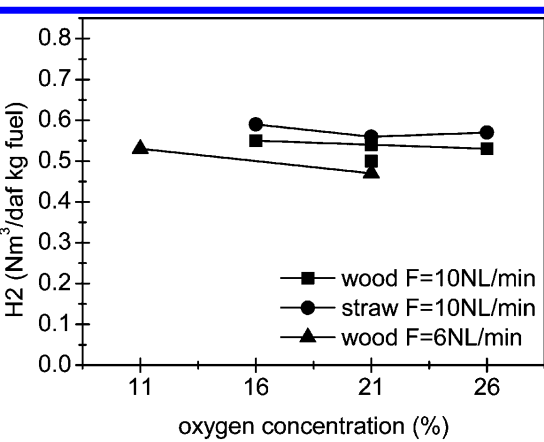

(b) $\mathrm{H}_{2}$

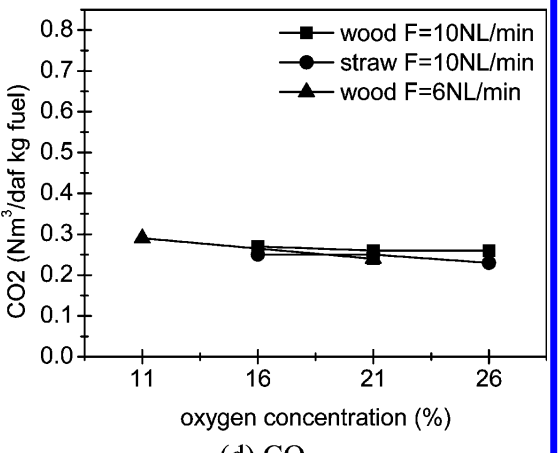

(d) $\mathrm{CO}_{2}$

Figure 12. Effect of the oxygen concentration on the product yield during wood and straw gasification: feeder air flow = 6-10 NL/min; excess air ratio $=0.3$; steam $/$ carbon ratio $=0.5$; and reactor temperature $=1400{ }^{\circ} \mathrm{C}$.

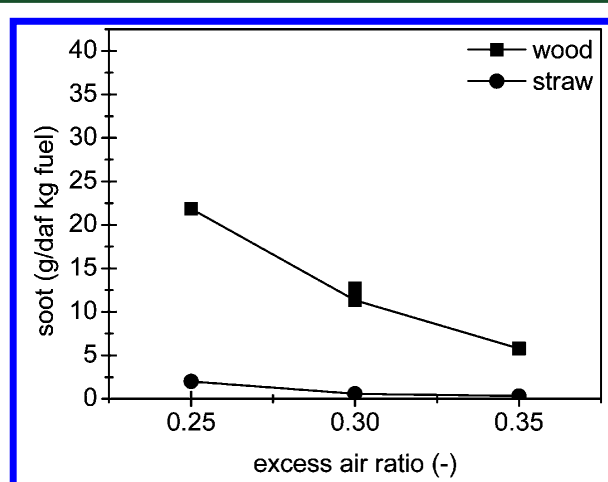

(a) soot

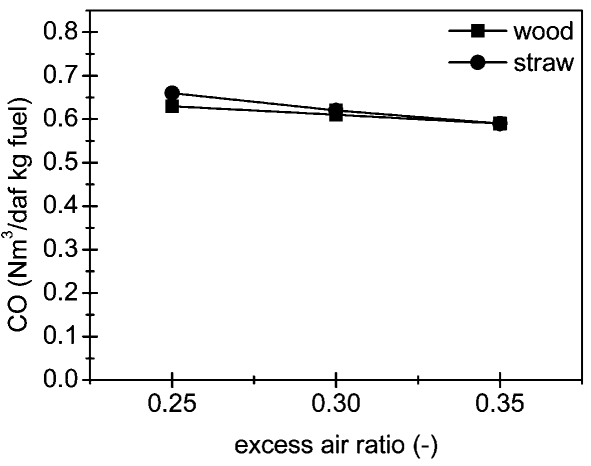

(c) $\mathrm{CO}$

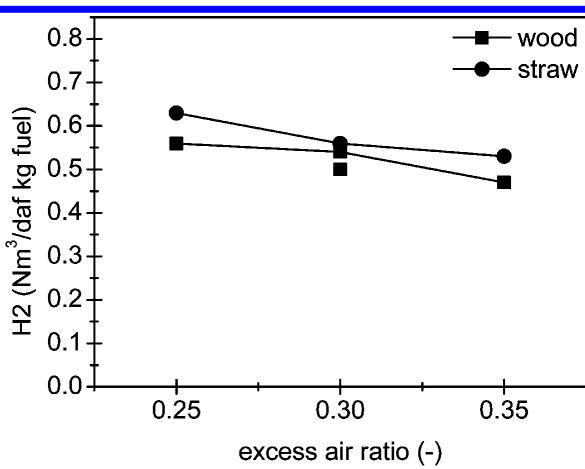

(b) $\mathrm{H}_{2}$

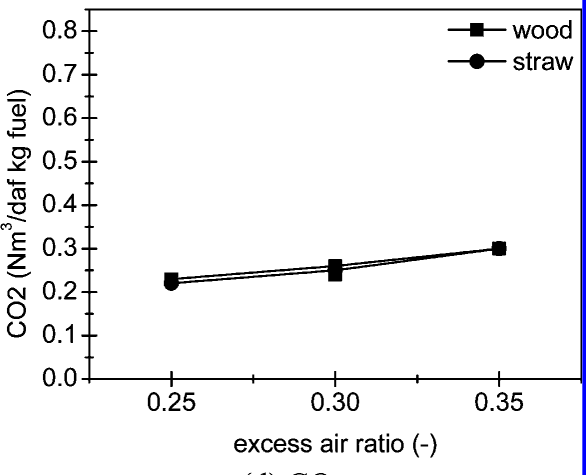

(d) $\mathrm{CO}_{2}$

Figure 13. Effect of the excess air ratio on the product yield during wood and straw gasification: feeder air flow $=10 \mathrm{NL} / \mathrm{min}$; oxygen concentration $=21 \%$; steam $/$ carbon ratio $=0.5$; and reactor temperature $=1400{ }^{\circ} \mathrm{C}$.

reactor temperature $\left.=1400{ }^{\circ} \mathrm{C}\right)$. The soot yield increased from 9.6 to $12.4 \mathrm{~g} / \mathrm{kg}$ fuel (daf basis) during wood gasification and from 0.5 to $1.0 \mathrm{~g} / \mathrm{kg}$ fuel (daf basis) during straw gasification when the oxygen concentration was increased from 16 to $26 \%$ with a feeder air flow of $10 \mathrm{NL} / \mathrm{min}$. The increasing oxygen concentration could raise the flame temperature, which may cause more soot formation. ${ }^{27}$ The $\mathrm{H}_{2}, \mathrm{CO}$, and $\mathrm{CO}_{2}$ yields were almost constant, independent of the oxygen concentration during both wood and straw gasification, and close to equilibrium at the nominal reactor temperature. During wood gasification, 


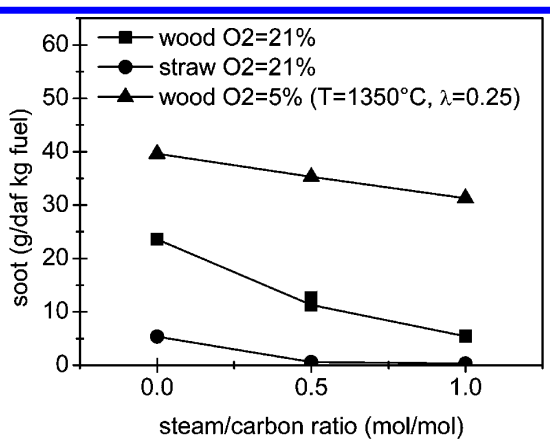

(a) soot

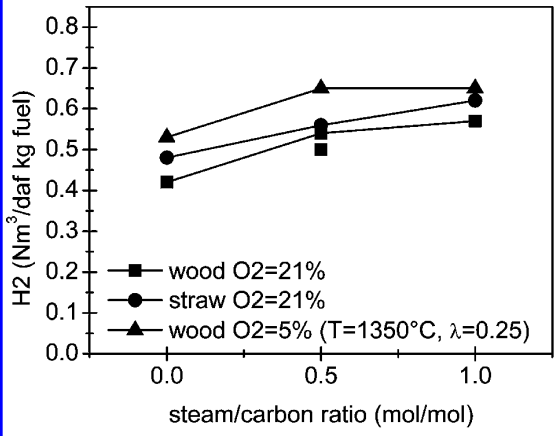

(b) $\mathrm{H}_{2}$

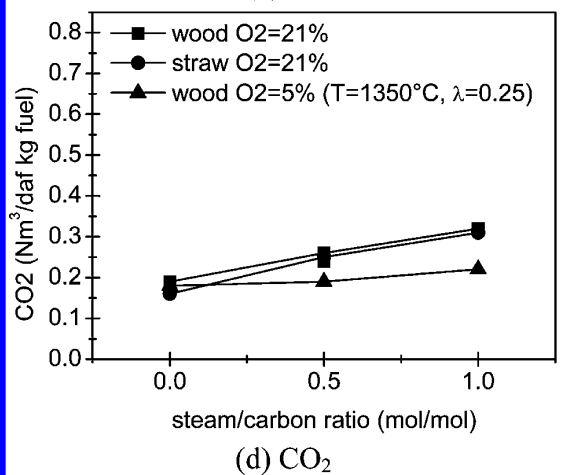

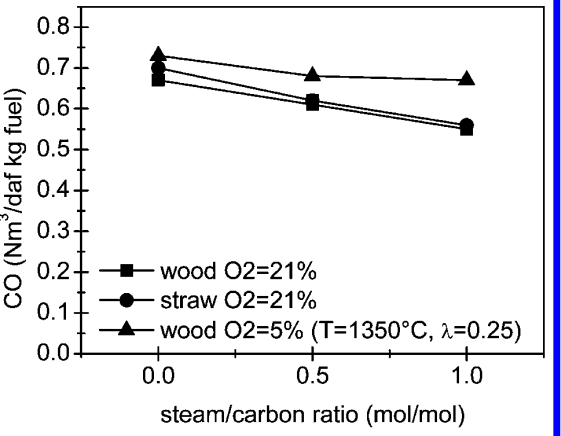

(c) $\mathrm{CO}$

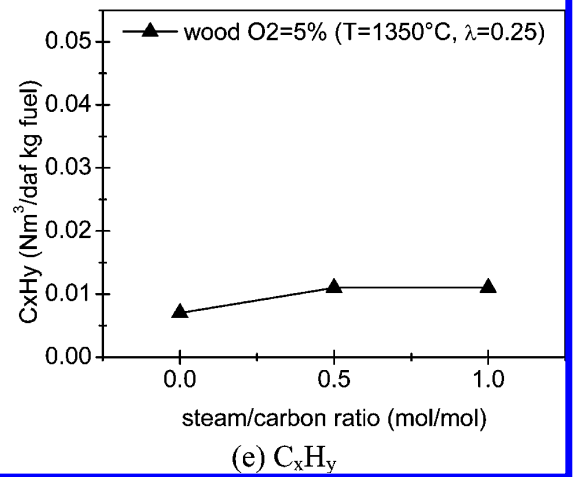

Figure 14. Effect of the steam/carbon ratio on the product yield during wood and straw gasification: feeder air flow $=10 \mathrm{NL} / \mathrm{min}$; in the present study, excess air ratio $=0.3$; and reactor temperature $=1400{ }^{\circ} \mathrm{C}$; in the previous study, ${ }^{20}$ excess air ratio $=0.25$; and reactor temperature $=1350{ }^{\circ} \mathrm{C}$.

similar trends of soot and gas product yields were observed when the oxygen concentration was increased from 11 to $21 \%$ with a feeder air flow of $6 \mathrm{NL} / \mathrm{min}$. The effect of the excess air ratio on the product yield during wood and straw gasification is shown in Figure 13. The applied excess air ratio was increased from 0.25 to 0.35 by lowering the fuel feeding rate with otherwise fixed operating parameters (feeder air flow $=10 \mathrm{NL} / \mathrm{min}$; oxygen concentration $=21 \%$; steam $/$ carbon ratio $=0.5$; and reactor temperature $=1400{ }^{\circ} \mathrm{C}$ ). The soot yield decreased obviously from 21.8 to $5.8 \mathrm{~g} / \mathrm{kg}$ fuel (daf basis) and from 2.0 to $0.3 \mathrm{~g} / \mathrm{kg}$ fuel (daf basis) during wood and straw gasification, respectively, with an increasing excess air ratio from 0.25 to 0.35 . This is because more soot was oxidized and gasified. Also, it is likely that the initially generated soot was lower at the higher excess air ratio because of the lower fuel feeding rate and the higher oxygen content that could produce less and destroy more tar and soot precursors in the gas phase. ${ }^{28-30}$ The $\mathrm{H}_{2}$ yield decreased from 0.56 to $0.47 \mathrm{Nm}^{3} / \mathrm{kg}$ fuel (daf basis) during wood gasification and from 0.63 to $0.53 \mathrm{Nm}^{3} / \mathrm{kg}$ fuel (daf basis) during straw gasification, and the $\mathrm{CO}$ yield decreased from 0.63 to 0.59 $\mathrm{Nm}^{3} / \mathrm{kg}$ fuel (daf basis) during wood gasification and from 0.66 to $0.59 \mathrm{Nm}^{3} / \mathrm{kg}$ fuel (daf basis) during straw gasification. However, the $\mathrm{CO}_{2}$ yield increased approximately from 0.23 to $0.30 \mathrm{Nm}^{3} / \mathrm{kg}$ fuel (daf basis) during both wood and straw gasification because of the oxidation of $\mathrm{CO}$ and soot. Therefore, it can be summarized that increasing the excess air ratio by increasing the oxygen concentration noticeably affected the product yields and increasing the excess air ratio with a fixed oxygen concentration clearly decreased the yields of soot, $\mathrm{H}_{2}$, and $\mathrm{CO}$ while increased the $\mathrm{CO}_{2}$ yield, while increasing the oxygen concentration with a fixed excess air ratio only slightly increased the soot yield and nearly retained the yields of gas products. We can conclude that the effect of the excess air ratio on the syngas composition is much stronger than the effect of the oxygen concentration.

In Figures $9 \mathrm{~b}$ and $10 \mathrm{a}$, at $1000{ }^{\circ} \mathrm{C}$ with a feeder air flow of $10 \mathrm{NL} / \mathrm{min}$, the flame structures during wood combustion (excess air ratio $=1.1)$ and gasification (excess air ratio $=0.7$ ) are shown, respectively. Clearly, no soot was observed during combustion in Figure $9 \mathrm{~b}$, while soot was formed and escaped the flame during gasification in Figure 10a. In addition, a comparison between Figure 9c (combustion; excess air ratio $=1.1$ ) and Figure 10b (gasification; excess air ratio $=0.7$ ) shows similar results at $1000{ }^{\circ} \mathrm{C}$ with a feeder air flow of $15 \mathrm{NL} / \mathrm{min}$. The observations are quite in accordance with the experimental results shown in 


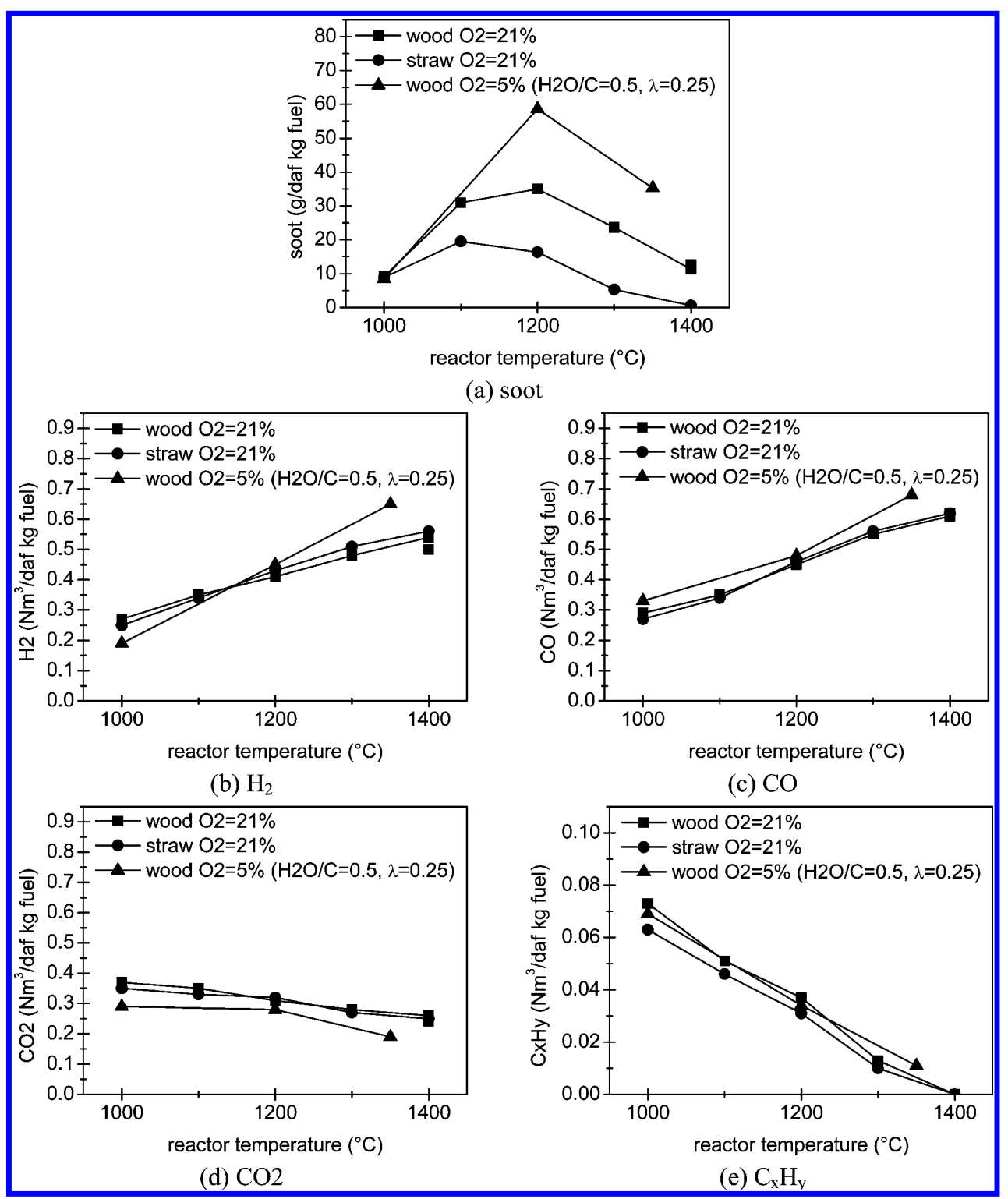

Figure 15. Effect of the reactor temperature on the product yield during wood and straw gasification: feeder air flow $=10 \mathrm{NL} / \mathrm{min}$; and steam $/ \mathrm{carbon}$ ratio $=0.5$; in the present study, excess air ratio $=0.3$; in the previous study, ${ }^{20}$ excess air ratio $=0.25$.

Figure 13a that the more oxidizing condition is employed, the less soot forms.

3.3.4. Steam/Carbon Ratio and Reactor Temperature. In our previous work, ${ }^{20}$ the effects of the steam/carbon ratio and reactor temperature on syngas composition during wood gasification with low oxygen concentration (5\%) were studied. To reveal the effects of the two parameters on syngas composition with a higher oxygen concentration, more experiments were carried out in the present study. Figure 14 shows the effect of the steam/carbon ratio on the product yield during wood and straw gasification with an oxygen concentration of $21 \%$. The steam/carbon ratio was increased from 0.0 to 1.0 with otherwise fixed operating parameters (feeder air flow $=10 \mathrm{NL} / \mathrm{min}$; excess air ratio $=0.3$; and reactor temperature $=1400{ }^{\circ} \mathrm{C}$ ). The soot yield decreased from 23.6 to $5.4 \mathrm{~g} / \mathrm{kg}$ fuel (daf basis) and from 5.4 to $0.3 \mathrm{~g} / \mathrm{kg}$ fuel (daf basis) during wood and straw gasification, respectively, by increasing the steam/carbon ratio from 0.0 to 1.0. During wood gasification, the $\mathrm{H}_{2}$ and $\mathrm{CO}_{2}$ yields increased steadily from 0.42 to $0.57 \mathrm{Nm}^{3} / \mathrm{kg}$ fuel (daf basis) and from 0.19 to $0.32 \mathrm{Nm}^{3} / \mathrm{kg}$ fuel (daf basis), respectively, while the
$\mathrm{CO}$ yield gradually decreased from 0.66 to $0.55 \mathrm{Nm}^{3} / \mathrm{kg}$ fuel (daf basis). During straw gasification, a similar variation of the gas compositions was found. These results were consistent with our previous results, ${ }^{20}$ also shown in Figure 14. During wood gasification, more soot was produced in the previous study than in the present study because the applied reactor temperature $\left(T=1350^{\circ} \mathrm{C}\right)$ and excess air ratio $(\lambda=0.25)$ were lower and the residence time $(t=2.2 \mathrm{~s})$ was shorter in the previous study. For the same reason, $\mathrm{C}_{x} \mathrm{H}_{y}$ was produced only in the previous study. Thus, we can conclude that the effect of the steam/carbon ratio on syngas product distribution with different oxygen concentrations is consistent.

Figure 15 shows the effect of the reactor temperature on the product yield during wood and straw gasification with an oxygen concentration of $21 \%$. The applied reactor temperature range was between 1000 and $1400{ }^{\circ} \mathrm{C}$ with otherwise fixed operating parameters (feeder air flow $=10 \mathrm{NL} / \mathrm{min}$; excess air ratio $=0.3$; and steam/carbon ratio $=0.5)$. During wood gasification, the soot yield had a low value of $9.2 \mathrm{~g} / \mathrm{kg}$ fuel (daf basis) at $1000{ }^{\circ} \mathrm{C}$, increased to a maximum of $35.0 \mathrm{~g} / \mathrm{kg}$ fuel (daf basis) 


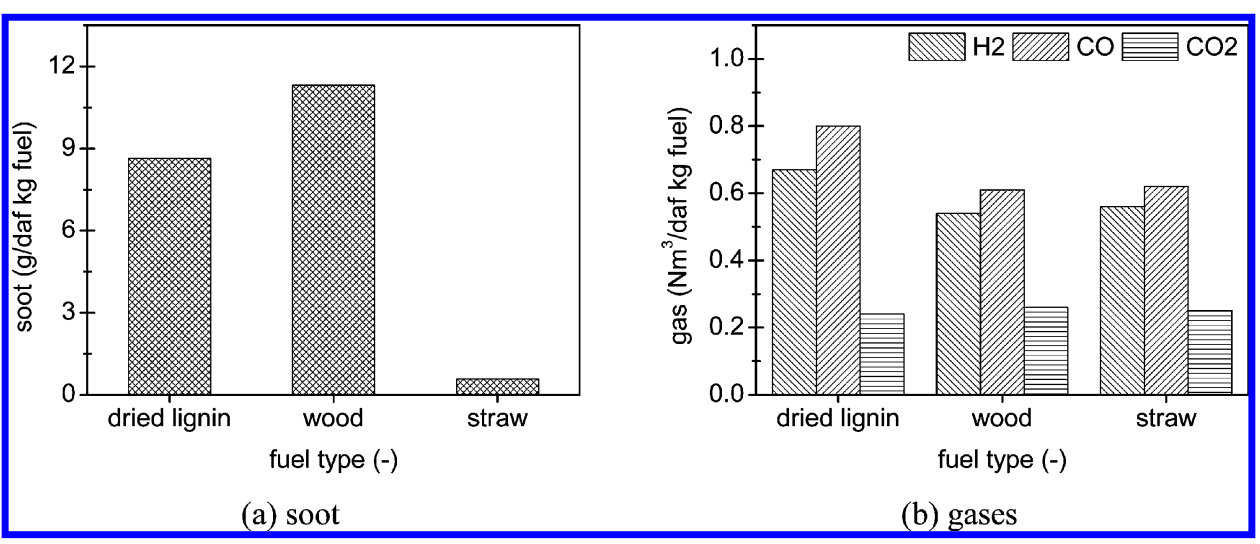

Figure 16. Effect of the biomass type on the product yield during biomass gasification: feeder air flow $=10 \mathrm{NL} / \mathrm{min}$; oxygen concentration $=21 \%$; excess air ratio $=0.3$; steam $/$ carbon ratio $=0.5$; and reactor temperature $=1400{ }^{\circ} \mathrm{C}$.

at $1200{ }^{\circ} \mathrm{C}$, and then started to decline and finally reached 11.3 $\mathrm{g} / \mathrm{kg}$ fuel (daf basis) at $1400{ }^{\circ} \mathrm{C}$. During straw gasification, the soot yield had a similar trend, except that the peak value of $19.5 \mathrm{~g} / \mathrm{kg}$ fuel (daf basis) was achieved at $1100{ }^{\circ} \mathrm{C}$. From 1000 to $1400{ }^{\circ} \mathrm{C}$, during both wood and straw gasification, the yields of $\mathrm{H}_{2}$ and $\mathrm{CO}$ monotonically increased from about 0.26 to about $0.56 \mathrm{Nm}^{3} / \mathrm{kg}$ fuel (daf basis) and from about 0.28 to about 0.62 $\mathrm{Nm}^{3} / \mathrm{kg}$ fuel (daf basis), respectively. Simultaneously, the $\mathrm{CO}_{2}$ yield monotonically decreased from about 0.36 to about 0.26 $\mathrm{Nm}^{3} / \mathrm{kg}$ fuel (daf basis), and the $\mathrm{C}_{x} \mathrm{H}_{y}$ yield had a steady decline from about $0.07 \mathrm{Nm}^{3} / \mathrm{kg}$ fuel (daf basis) at $1000{ }^{\circ} \mathrm{C}$ to disappearance at $1400{ }^{\circ} \mathrm{C}$. It should be remarked that no $\mathrm{C}_{x} \mathrm{H}_{y}$ was produced at $1400{ }^{\circ} \mathrm{C} . \mathrm{CH}_{4}$ was the most abundant component of $\mathrm{C}_{x} \mathrm{H}_{y}$, corresponding to a level of $85-100 \%$. The $\mathrm{CH}_{4}$ yield also decreased steadily with the increasing temperature. The results from this work were in good agreement with the previous results, also shown in Figure 15. In comparison to the present study, the soot yield was higher in the previous study, where the applied excess air ratio $(\lambda=0.25)$ was lower and the residence time $(t=2.2-3.0 \mathrm{~s})$ was shorter at each temperature, as explained above.

3.4. Effects of Biomass Types. The gasification behaviors of wood and straw are compared in Figures 12-15. It can be observed that the soot yield is significantly lower during straw gasification. This could be due to the high potassium content in straw that might catalyze char formation during pyrolysis at the expense of volatiles, which then lead to less soot formation. Besides, the potassium species, which must be present in the gas phase during the high-temperature gasification process, could adsorb and deposit on the surface of the soot particles in the reactor. Thus, another reason for the low soot yield during straw gasification might be that potassium has a catalytic effect on the soot gasification reactions. ${ }^{31-35}$ The oxidation and gasification rates of the soot that was produced in wood and straw gasification experiments, respectively, were analyzed by a thermogravimetric apparatus (Netzsch STA-449C). In the analysis, $5 \mathrm{mg}$ filter samples (almost pure soot during wood gasification, while mixtures of soot, $\mathrm{KCl}$, and $\mathrm{K}_{2} \mathrm{SO}_{4}$ during straw gasification) were loaded in an alumina crucible and heated at $10{ }^{\circ} \mathrm{C} / \mathrm{min}$ from room temperature to $1400^{\circ} \mathrm{C}$. The applied gas environment was $20 \% \mathrm{O}_{2}$ or $\mathrm{CO}_{2}$ in $\mathrm{N}_{2}$. We found that the initial oxidation temperature of wood soot was about $11{ }^{\circ} \mathrm{C}$ lower than that of straw soot, while the initial gasification temperature of straw soot was about $115^{\circ} \mathrm{C}$ lower than that of wood soot probably because of the presence of potassium in straw. These observations might confirm the catalytic effect of potassium on soot with respect to
$\mathrm{CO}_{2}$ gasification. Wood and straw gasification provided quite similar gas compositions, which was in agreement with other studies. ${ }^{15,36}$ The gasification behaviors of the three fuels, dried lignin, wood, and straw, are compared in Figure 16. The three gasification experiments were carried out at the same operating conditions (feeder air flow $=10 \mathrm{NL} / \mathrm{min}$; oxygen concentration = $21 \%$; excess air ratio $=0.3$; steam $/$ carbon ratio $=0.5$; and reactor temperature $=1400{ }^{\circ} \mathrm{C}$ ). The soot yield was $8.6 \mathrm{~g} / \mathrm{kg}$ fuel (daf basis) during dried lignin gasification, which was a little lower than that during wood gasification $(11.3 \mathrm{~g} / \mathrm{kg}$ fuel (daf basis)) but much higher than that during straw gasification $(0.3 \mathrm{~g} / \mathrm{kg}$ fuel (daf basis $))$. Besides, in comparison to wood and straw gasification, the dried lignin gasification exhibited higher $\mathrm{H}_{2}$ and $\mathrm{CO}$ yields, a lower $\mathrm{CO}_{2}$ yield, and no $\mathrm{C}_{x} \mathrm{H}_{y}$ as well.

\section{CONCLUSION}

Biomass gasification has been investigated in a laboratory-scale atmospheric pressure entrained flow reactor with the purpose of obtaining insight into the effects of operating parameters and biomass types on gas product distribution and soot formation. In the present study, the effects of six operating parameters (residence time, feeder air flow, oxygen concentration, excess air ratio, steam/carbon ratio, and reactor temperature) were investigated. Wood, straw, and dried lignin were used as fuels. Besides a comprehensive experimental study on biomass gasification, biomass pyrolysis was also investigated to obtain a better understanding of the whole gasification process.

During entrained flow gasification, $\mathrm{H}_{2}$ and $\mathrm{CO}$ are the desired products, while soot is the main byproduct and is required to be removed or minimized. In comparison to pyrolysis, the soot yield during gasification was lower, probably partly because of lower initially generated soot amounts and partly because of soot gasification with $\mathrm{CO}_{2}$ and $\mathrm{H}_{2} \mathrm{O}$. A longer residence time and larger feeder air flow (better mixing) reduced the soot yield, while the yields of $\mathrm{H}_{2}$ and $\mathrm{CO}$ were nearly unchanged. The effects of the oxygen concentration and excess air ratio on syngas products were investigated. When the oxygen concentration was increased but the excess air ratio was fixed, the soot yield increased slightly and the yields of gas products were almost kept constant. When the excess air ratio was increased but the oxygen concentration was fixed, the yields of soot, $\mathrm{H}_{2}$, and $\mathrm{CO}$ decreased, while the $\mathrm{CO}_{2}$ yield increased. Both the previous study $^{20}$ and the present study, with oxygen concentrations of 5 and $21 \%$, respectively, revealed that high temperatures and steam addition reduced the soot yield and increased the $\mathrm{H}_{2}$ yield and high temperatures also increased the $\mathrm{CO}$ yield. Wood, straw, 
and dried lignin gasification exhibited similar gas compositions. However, the soot yield was much lower during straw gasification than that during both wood and dried lignin gasification. It may be due to the high potassium content in straw that might catalyze char formation during pyrolysis at the expense of volatiles, which then lead to less soot formation or, alternatively, that potassium has a catalytic effect on the soot gasification reactions. On the basis of our work, it can be concluded that high-temperature $\left(>1200{ }^{\circ} \mathrm{C}\right)$ entrained flow air/steam gasification of biomass can achieve a high carbon conversion within a few seconds of residence time and a high-quality syngas with a low but not negligible soot yield and very low hydrocarbon content and, in particular, without tar. Increasing the residence time, feeder air flow, and excess air ratio can further reduce the amount of soot in syngas.

\section{ASSOCIATED CONTENT}

\section{S Supporting Information}

Detailed data of the carbon mass balance in all conducted experiments (listed in Table 2 and shown in Figure 4). This material is available free of charge via the Internet at http://pubs. acs.org.

\section{AUTHOR INFORMATION}

\section{Corresponding Author}

*Telephone: +45-45-25-28-41. Fax: +45-45-88-22-58. E-mail: aj@kt.dtu.dk.

\section{Notes}

The authors declare no competing financial interest.

\section{ACKNOWLEDGMENTS}

This work is part of the Combustion and Harmful Emission Control (CHEC) Research Centre at the Department of Chemical and Biochemical Engineering, Technical University of Denmark. The Danish Research Council for Technology and Production under Project 09-064201/FTP and the Danish Energy Agency are acknowledged for sponsoring the project. DONG Energy Power A/S is acknowledged for fuel analysis. We thank Nikolaj Vinterberg Nissen for technical support and Jørgen Busk for straw supply.

\section{REFERENCES}

(1) International Energy Agency (IEA). World Energy Outlook; IEA: Paris, France, 2008.

(2) Johansson, T. B.; Kelly, H.; Reddy, A. K. N.; Williams, R.; Drennen, T. E. Renewable Energy: Sources for Fuels and Electricity; Island Press: Washington, D.C., 1992; pp 593-651.

(3) Drax Group plc. AnonymousBiomass: The Fourth Energy Source; Drax Group plc: Selby, U.K., 2012; www.draxpower.com/files/page/ 84635/Biomass the fourth_energy_source_FINAL.pdf.

(4) McKendry, P. Bioresour. Technol. 2002, 1, 47-54.

(5) Demirbas, A. Fuel 2001, 13, 1885-1891.

(6) Rabah, M. A.; Eldighidy, S. M. Int. I. Hydrogen Energy 1989, 4, $221-$ 227.

(7) McKendry, P. Bioresour. Technol. 2002, 1, 55-63.

(8) Demirbas, A. Prog. Energy Combust. Sci. 2004, 2, 219-230.

(9) McKendry, P. Bioresour. Technol. 2002, 1, 37-46.

(10) Basu, P. Biomass Gasification and Pyrolysis: Practical Design and Theory; Academic Press: New York, 2010; pp 1-25.

(11) Hernández, J. J.; Aranda-Almansa, G.; Bula, A. Fuel Process. Technol. 2010, 6, 681-692.

(12) Zhao, Y.; Sun, S.; Zhou, H.; Sun, R.; Tian, H.; Luan, J.; Qian, I. Fuel Process. Technol. 2010, 8, 910-914.
(13) Zhao, Y.; Sun, S.; Tian, H.; Qian, J.; Su, F.; Ling, F. Bioresour. Technol. 2009, 23, 6040-6044.

(14) Zhou, J.; Chen, Q.; Zhao, H.; Cao, X.; Mei, Q.; Luo, Z.; Cen, $\underline{K}$. Biotechnol. Adv. 2009, 5, 606-611.

(15) Lapuerta, M.; Hernández, J. J.; Pazo, A.; López, I. Fuel Process Technol. 2008, 9, 828-837.

(16) Crnomarkovic, N.; Repic, B.; Mladenovic, R.; Neskovic, O.; Velikovic, M. Fuel 2007, 1-2, 194-202.

(17) Milne, T. A.; Abatzoglou, N.; Evans, R. J. Biomass Gasifier "Tars": Their Nature, Formation, and Conversion; National Renewable Energy Laboratory (NREL): Golden, CO, 1998.

(18) Morf, P.; Hasler, P.; Nussbaumer, T. Fuel 2002, 7, 843-853.

(19) Evans, R. J.; Milne, T. A. Energy Fuels 1987, 2, 123-137.

(20) Qin, K.; Lin, W.; Jensen, P. A.; Jensen, A. D. Fuel 2012, 589-600.

(21) Kriengsak, S. N.; Buczynski, R.; Gmurczyk, J.; Gupta, A. K. Environ. Eng. Sci. 2009, 4, 739-744.

(22) Van Paasen, S. V. B.; Kiel, J. H. A.; Neeft, J. P. A.; Knoef, H. A. M.; Buffinga, G. J.; Zielke, U. Guideline for Sampling and Analysis of Tars and Particles in Biomass Producer Gases; European Committee for Standardization (CEN): Brussels, Belgium, 2002.

(23) Ahrenfeldt, J.; Henriksen, U. B.; Münster-Swendsen, J.; Fink, A.; Clausen, L. R.; Christensen, J. M.; Qin, K.; Lin, W.; Jensen, P. A.; Jensen., A. D.Production of Methanol/DME from Biomass: EFP06; Technical University of Denmark: Lyngby, Denmark, 2011.

(24) Wang, Y.; Kinoshita, C. Sol. Energy 1992, 3, 153-158.

(25) Chen, G.; Andries, J.; Luo, Z.; Spliethoff, H. Energy Convers. Manage. 2003, 11, 1875-1884.

(26) Zhao, Y.; Sun, S.; Tian, H.; Qian, J.; Su, F.; Ling, F. Bioresour. Technol. 2009, 23, 6040-6044.

(27) Glassman, I.; Yaccarino, P. Combust. Sci. Technol. 1980, 3-4, $107-114$.

(28) Glassman, I. Symp. (Int.) Combust., [Proc.] 1989, 1, 295-311.

(29) Fletcher, T. H.; Ma, J.; Rigby, J. R.; Brown, A. L.; Webb, B. W. Prog. Enerov Combust. Sci. 1997, 3, 283-301.

(30) Stanmore, B. R.; Brilhac, J. F.; Gilot, P. Carbon 2001, 15, $2247-$ 2268.

(31) Howard, J. B.; Kausch, W. J., Jr. Prog. Energy Combust. Sci. 1980, 3, 263-276.

(32) Haynes, B. S.; Jander, H.; Wagner, H. Symp. (Int.) Combust., [Proc.] 1979, 1, 1365-1374.

(33) Tappe, M.; Haynes, B.; Kent, J. Combust. Flame 1993, 3, 266-273.

(34) Bulewicz, E. M.; Evans, D. G.; Padley, P. J. Symp. (Int.) Combust., [Proc.] 1975, 1, 1461-1470.

(35) Glarborg, P. Proc. Combust. Inst. 2007, 1, 77-98.

(36) Lv, Y.; Ji, C.; Guo, L. J. Xi'an Jiaotong Univ. 2005, 238-242. 